\author{
AGNIESZKA NALEWAJEK ${ }^{1}$ \\ Wydział Nauk Historycznych \\ Uniwersytet Kardynała Stefana Wyszyńskiego, Warszawa \\ ORCID: 0000-0001-5155-4511
}

\title{
PRAKTYKI RELIGIJNE KRÓLA JANA OLBRACHTA W ŚWIETLE RACHUNKÓW NADWORNYCH ${ }^{2}$
}

\section{Religious Practices of King John I Albert (Polish: Jan Olbracht) in the Light of Court Accounts}

\section{Abstract}

John I Albert's (Jan Olbracht's) (1492-1501) royal accounts, preserved in the Central Archives of Historical Records in Warsaw, contain a considerable amount of hitherto unexploited information on the religious practices zealously performed by this successor of Casimir IV Jagiellonian (Kazimierz Jagiellończyk). He upheld the traditions of piety (pietas regia) forged in the times of the preceding kings of the Jagiellonian dynasty. John I Albert made pilgrimages to the most important Polish sanctuaries and was a generous benefactor to the mendicant monasteries and infirmaries for the poor. He would also conscientiously perform daily and festive religious practices.

Keywords: King John I Albert (Jan Olbracht) (1492-1501), Jagiellonian dynasty, the Jagiellons, religious practices, piety, royal accounts

\section{Streszczenie}

Rachunki królewskie Jana Olbrachta (1492-1501) zachowane w Archiwum Głównym Akt Dawnych w Warszawie zawierają szereg niewykorzystanych informacji dotyczących praktyk religijnych, które gorliwie wypełniał następca Kazimierza Jagiellończyka. Podtrzymał on tradycje pobożności (pietas regia) ukształtowane w czasach poprzednich królów z dynastii Jagiellonów. Jan Olbracht odbył pielgrzymki do najważniejszych polskich sanktuariów oraz hojnie wspierał jałmużną klasztory mendykanckie i szpitale dla ubogich. Przykładnie wypełniał on również codzienne i odświętne praktyki religijne.

\footnotetext{
1 Dr Agnieszka Nalewajek - adiunkt w Katedrze Historii Nowożytnej w Instytucie Historii WNH UKSW w Warszawie. Prowadzi badania nad kulturą i społeczeństwem staropolskim, polskim dworem królewskim, rodami szlacheckimi. Email: a.nalewajek@uksw.edu.pl.

2 Artykuł jest oparty na referacie pt. Tamquam verus christiane religionis zelator. Praktyki religijne króla Jana Olbrachta przedstawionym przez autorkę na konferencji Polityka kościelna i praktyki religijne Jagiellonów na Zamku w Oświęcimiu w dniach 18-20 października 2018 r.
} 
Słowa kluczowe: król Jan Olbracht (1492-1501), dynastia Jagiellonów, Jagiellonowie, praktyki religijne, pobożność, rachunki królewskie

$\mathrm{W}$ nekrologu sporządzonym po śmierci króla Jana Olbrachta (1492-1501) na kartach Kodeksu Baltazara Behema powstałego w pierwszych latach XVI wieku zapisano, że król zmarł przyjąwszy komunię i namaszczenie chorych tamquam verus christianae religionis zelator $^{3}$. W świetle tych słów rodzi się pytanie o podejście władcy, do którego przylgnęło miano rozpustnika, do wypełniania praktyk religijnych ${ }^{4}$. Świadectwem stosunku monarchy do obowiązków religijnych są wydatki na cele kościelne odnotowane w rachunkach królewskich Jana Olbrachta, które zachowały się do czasów obecnych. Bezcenne źródła do badań nad praktykami religijnymi władcy stanowią przechowywane w Archiwum Głównym Akt Dawnych w Warszawie księgi rachunkowe o sygnaturach 20 i 22, które zawierają podręczne rejestry wydatków nadwornych z lat 1492-1497, a także fragment księgi rachunkowej nr 28, będący wykazem wydatków na potrzeby królewskie z 1501 r. ${ }^{5}$ Przynoszą one bardzo liczne informacje ukazujące Jana Olbrachta przez pryzmat obowiązków religijnych władcy.

Nieprzypadkowo pierwsza ze wzmianek wskazujących na wypełnianie przez króla praktyk religijnych, która znalazła się w jego rachunkach nadwornych, dotyczyła wydatku w kwocie 2 florenów na ofertorium w uroczystość św. Stanisława 27 września 1492 r. ${ }^{6}$ Zapis ten wprowadza w główny nurt pobożności władców z dynastii Jagiellonów związany ze szczególnym kultem świętego Stanisława7. Wspomnienie przeniesienia relikwii biskupa ze Skałki na Wawel przypadło cztery dni po ceremonii koronacji Jana Olbrachta, który został namaszczony i otrzymał koronę przy konfesji św. Stanisława w katedrze wawelskiej

\footnotetext{
3 M. Starzyński, Dwa nekrologi Jana Olbrachta (z krakowskiej księgi radzieckiej i Kodeksu Baltazara Behema, „Roczniki Historyczne”, 72/2006, s. 135. Król Jan Olbracht zmarł w Toruniu 17 czerwca 1501 r. Zob. F. Papée, Jan Olbracht, Kraków 2006, s. 198, 232.

4 Praktyki religijne króla Jana Olbrachta są zagadnieniem wzbudzającym zainteresowanie badaczy zajmujących się postacią władcy oraz problematyką pobożności Jagiellonów, któremu warto poświęcić więcej uwagi. Zob. F. Papée, dz. cyt., s. 10-11; U. Borkowska, Dynastia Jagiellonów w Polsce, Warszawa 2011, s. 397-424; taż, Codzienny $i$ odświętny ceremoniat religijny na dworze Jagiellonów, w: Theatrum ceremoniale na dworze książat i królów Polski. Materiały z konferencji naukowej zorganizowanej przez Zamek Królewski na Wawelu i Instytut Historii Uniwersytetu Jagiellońskiego w dniach 23-25 marca 1998, red. M. Markiewicz, R. Skowron, Kraków 1999, s. 61-85; taż, Królewskie miłosierdzie, w: Kultura średniowieczna i staropolska. Studia ofiarowane Aleksandrowi Gieysztorowi w pięćdziesięciolecie pracy naukowej, red. B. Gawinowa i in., Warszawa 1991, s. 683-694; taż, Pietas regia. Formy królewskiej pobożności w późnośredniowiecznej Polsce, w: Król w Polsce XIV i XV wieku, red. A Marzec, M. Wilamowski, Kraków 2006, s. 39-56; taż, Polskie pielgrzymki Jagiellonów, w: Peregrinationes. Pielgrzymki w kulturze dawnej Europy, red. H. Manikowska, H. Zaremska, Warszawa 1995, s. 189-190; taż, Rachunki królewskie jako źródło do poznania praktyk religijnych Jagiellonów, w: Peregrinatio ad veritatem. Studia ofiarowane profesor Aleksandrze Witkowskiej OSU z okazji 40-lecia pracy naukowej, red. U. Borkowska i in., Lublin 2004, s. 47-64; A. Nalewajek, Na królewskim dworze Jana Olbrachta, ,Roczniki Humanistyczne”, 59/2011, s. 76-77; Z. Zyglewski, Rola krakowskich mendykantów w kształtowaniu pobożności Jagiellonów na przełomie XV i XVI wieku, w: Mendykanci w średniowiecznym Krakowie, red. K. Ożóg, T. Gałuszka OP, A. Zajchowska, Kraków 2008, s. 41-57.

5 Archiwum Główne Akt Dawnych w Warszawie, Archiwum Skarbu Koronnego, Oddział 1, Rachunki Królewskie, sygn. 20, 22, 28 (dalej: Rk). Zob. U. Borkowska, Rachunki królewskie, dz. cyt., s. 50, 58.

6 Rk 20, s. 2. Kolejną okazję do udziału w uroczystościach związanych ze świętem ku czci św. Stanisława w Krakowie Jan Olbracht miał dopiero 27 września 1496 r. Król złożył wtedy na ofertorium również 2 floreny. Rk 22 , k. 88. Podobne ofiary oraz datki dla ubogich były przekazywane podczas uroczystości poza Krakowem. Rk 20, k. 53; Rk 22, k. 36v, 67, 80v.

7 U. Borkowska, Pobożność rodziny Kazimierza Jagiellończyka, „Analecta Cracoviensia”, 16/1984, s. 26-27; taż, Dynastia Jagiellonów, dz. cyt., s. 419-421.
} 
w niedzielę 23 września 1492 r. ${ }^{8}$ Pierwsza monarsza celebracja przez następcę Kazimierza Jagiellończyka uroczystości poświęconej patronowi Królestwa Polskiego stanowi przesłankę przemawiającą za tym, że Jan Olbracht dopełnił obowiązku odbycia pielgrzymki pokutnej na Skałkę w przeddzień jego koronacji ${ }^{9}$.

W katedrze wawelskiej uroczyste nabożeństwo ku czci św. Stanisława, poświadczone wydatkiem 4 florenów na ofertorium, miało miejsce po przyjeździe władcy z wyprawy do Lewoczy 16 maja 1494 r. ${ }^{10} \mathrm{Na}$ dworze Jana Olbrachta zachowany został zwyczaj pielgrzymek monarszych do konfesji św. Stanisława związany z ceremoniami wjazdów królewskich do Krakowa, a także praktyka piątkowego pielgrzymowania przez Jagiellonów do miejsca męczeńskiej śmierci biskupa ${ }^{11}$. W ramach pielgrzymki na Skałkę sprawowanej w piątek 26 sierpnia 1496 r. król odwiedził augustiański kościół pod wezwaniem św. Katarzyny, gdzie złożył na ofertorium około 4 florenów ${ }^{12}$.

W 1496 r. Jan Olbracht wziął udział w krakowskich obchodach święta Rozesłania Apostołów, które upamiętniały zwycięstwo pod Grunwaldem z $1410 \mathrm{r}$. W przypadającą w piątek uroczystość monarcha uczestniczył w procesji dziękczynnej wiodącej z katedry wawelskiej na Skałkę, a także do kościoła św. Jadwigi na Stradomiu ${ }^{13}$. Zwyczaj ten podkreślał wiarę we wstawiennictwo świętych patronów Królestwa Polskiego w zwycięskiej bitwie z Zakonem Krzyżackim ${ }^{14}$.

Odwiedzanie krakowskich sanktuariów i uczestnictwo w nabożeństwach sprawowanych w miejscach kultu religijnego wpisywało się w tradycję peregrynacji królewskich podejmowanych przez Jagiellonów. W pierwszym rzędzie obejmowała ona pielgrzymowanie na Łysą Górę do relikwii Świętego Krzyża znajdujących się w benedyktyńskim klasztorze Świętej Trójcy, do sanktuarium Bożego Ciała w Poznaniu, na Wawel i Skałkę, a także na Jasną Górę w Częstochowie do ikony Matki Bożej ${ }^{15}$. Jan Olbracht w okresie swego niedługiego panowania podtrzymał tę tradycję. Przybył w ramach pielgrzymek monarszych do wszystkich głównych polskich sanktuariów narodowych ${ }^{16}$.

Trasa pierwszej podróży królewskiej obejmującej pobyt na sejmie w Piotrkowie, a następnie w Wielkopolsce, którą władca odbył po koronacji w 1493 r., uwzględniała uroczyste nabożeństwo w kościele Bożego Ciała w dniu przyjazdu króla do Poznania. Jan Olbracht przybył jako pielgrzym do ufundowanego przez Władysława Jagiełłę sanktuarium cudu eucharystycznego w piątek 15 marca 1493 r., a na ofertorium przeznaczono wtedy aż 10

\footnotetext{
$8 \quad$ F. Papée, dz. cyt., s. 38-39, 221.

9 Por. Z. Dalewski, Ceremoniat koronacyjny królów polskich w XV i początkach XVI wieku, „Kwartalnik Historyczny", 102/1995, z. 3-4, s. 37.

$10 \quad \operatorname{Rk} 22, \mathrm{k} .23 \mathrm{v}, 26$.

11 U. Borkowska, Dynastia Jagiellonów, dz. cyt., s. 419-421; taż, Polskie pielgrzymki Jagiellonów, dz. cyt., s. 200$-201$.

12 Rk 22, k. 86.

13 Rk 22, k. 83v. Zob. T. Lalik, O patriotycznym święcie Rozesłania Apostołów w Małopolsce w XV w., „Studia Źródłoznawcze”, 26/1981, s. 25; U. Borkowska, Dynastia Jagiellonów, dz. cyt., s. 403.

14 U. Borkowska, Dynastia Jagiellonów, dz. cyt., s. 461.

15 Taż, Pobożność rodziny, dz. cyt., s. 26-27; taż, Polskie pielgrzymki Jagiellonów, dz. cyt., s. 190; taż, Dynastia Jagiellonów, dz. cyt., s. 404.

16 Taż, Polskie pielgrzymki Jagiellonów, dz. cyt., s. 187, 190; taż, Dynastia Jagiellonów, dz. cyt., s. 405, 410; Z. Zyglewski, Monarcha a klasztor w Polsce późnego średniowiecza, Bydgoszcz 2009, s. 290; A. Nalewajek, dz. cyt., s. 77.
} 
florenów ${ }^{17}$. W czasie trwającego kilka miesięcy pobytu w Poznaniu w 1493 r. król następnie parokrotnie odwiedził kościół Bożego Ciała, którym opiekowali się karmelici. Zapisy w rachunkach wskazują, że udał się on do sanktuarium Trzech Hostii, z których według opisów cudu wypłynęła Krew Pańska, w dniu Męki Chrystusa w Wielki Piątek ${ }^{18}$. Klasztor karmelitów dostawał jałmużnę królewską przekazywaną mendykantom ${ }^{19}$. Jeden z datków kościół Bożego Ciała otrzymał w okolicach święta Rozesłania Apostołów upamiętniającego zwycięstwo pod Grunwaldem, które władca obchodził wówczas w Poznaniu ${ }^{20}$.

Do sanktuarium Krzyża Świętego na Łysej Górze Jan Olbracht przybył w 1494 r. podczas podróży królewskiej z Krakowa na sejm zwołany w Radomiu, skąd następnie udał się do Prus. W progi klasztoru Świętej Trójcy król zawitał w niedzielę 8 września w uroczystość Narodzenia Najświętszej Marii Panny ${ }^{21}$. Powodem podjęcia w tym czasie przez władcę peregrynacji do relikwii Drzewa Krzyża Świętego przechowywanej przez benedyktynów na Łysej Górze mogło być zbliżające się święto Podniesienia Krzyża Świętego. Jan Olbracht w sanktuarium potwierdził pieczę królewską dynastii jagiellońskiej nad centrum kultu Krzyża Świętego poprzez wydanie dokumentu, w którym dokonał zatwierdzenia wcześniejszych przywilejów klasztoru Świętej Trójcy na Łysej Górze ${ }^{22}$.

Kolejnym ważnym miejscem kultu Drzewa Krzyża na ziemiach polskich, do którego trafiły relikwie Krzyża Świętego, stał się dominikański klasztor św. Stanisława w Lublinie. Rachunki nadworne w związku z pobytem władcy w mieście w 1495 r. odnotowują wydatki świadczące o wsparciu pieniężnym lubelskich zakonników. Po wyjeździe z Lublina przed końcem roku władca przekazał na rzecz klasztoru darowiznę w kwocie 20 florenów ${ }^{23}$. Zapewne Jan Olbracht odwiedzał tę świątynię także podczas późniejszych swych pobytów w Lublinie pod koniec 1496 i na początku $1497 \mathrm{r}^{24}$

Na trasie podróży podejmowanych przez Jana Olbrachta w pierwszych latach panowania nie było wyjazdu do prowadzonego przez paulinów sanktuarium Matki Bożej w Częstochowie $^{25}$. Już kilka miesięcy po koronacji Jan Olbracht wysłał tam swego kapelana Stanisława z Proszowic ${ }^{26}$. Władca nie zdołał pojechać do Częstochowy w połowie czerwca 1494 r., gdy potwierdził dokumentem przywileje klasztoru jasnogórskiego ${ }^{27}$. Zapewne nieprzypadkowo

\footnotetext{
17 Rk 20, k. 36, 40v. Zob. U. Borkowska, Polskie pielgrzymki Jagiellonów, dz. cyt., s. 190; Z. Zyglewski, Monarcha a klasztor, dz. cyt., s. 290.

18 Rk 20, k. 41. Wydatek ten odnotowany został pod wydatkami w Wielki Piątek, czyli 5 kwietnia. Z. Zyglewski podał, że król odwiedził kościół Bożego Ciała po raz drugi 18 marca. Por. Z. Zyglewski, Monarcha a klasztor, dz. cyt., s. 290.

19 Rk 20, k. 42, 45, 49v, 57v, 60v, 65, 68v, 70, 77, 78v, 79.

20 Rk 20, k. 67v. U. Borkowska, Polskie pielgrzymki Jagiellonów, dz. cyt., s. 189; taż, Dynastia Jagiellonów, dz. cyt., s. 408-409.

21 F. Papée, dz. cyt., s. 223; U. Borkowska, Polskie pielgrzymki Jagiellonów, dz. cyt., s. 186; taż, Dynastia Jagiellonów, dz. cyt., s. 405.

22 AGAD, Zbiór dokumentów pergaminowych, sygn. 1886. O opiece Jagiellonów nad klasztorem benedyktynów na Łysej Górze pisze szerzej U. Borkowska, Polskie pielgrzymki Jagiellonów, dz. cyt., s. 187-188; taż, Dynastia Jagiellonów, dz. cyt., s. 407.

23 Rk. 22, k. 73v. Por. Z. Zyglewski, Monarcha a klasztor, dz. cyt., s. 133.

24 F. Papée, dz. cyt., s. 226.

25 U. Borkowska, Jasna Góra w pobożności królów polskich, „Studia Claramontana”, 4/1983, s. 126-145; taż, Polskie pielgrzymki Jagiellonów, dz. cyt., s. 192-199; taż, Dynastia Jagiellonów, dz. cyt., s. 412-419.

26 Rk 20, k. 48v.

${ }^{27}$ Zbiór dokumentów OO. Paulinów w Polsce, t. 2, oprac. J. Zbudniewek, Warszawa 2004, nr 108.
} 
został poczyniony w tym czasie wydatek na różaniec określany jako pater noster ${ }^{28}$. Idea modlitwy różańcowej łączyła się z treścią kultu maryjnego, który stanowił jeden z głównych nurtów pobożności Jagiellonów. Stała się ona szczególnie bliska córkom i synom Kazimierza Jagiellończyka, również Janowi Olbrachtowi, co znalazło swój wyraz na miniaturze umieszczonej w Graduale ufundowanym dla katedry wawelskiej przez władcę pod koniec życia ${ }^{29}$. Więź religijna z sanktuarium Matki Bożej była stale podtrzymywana poprzez przynależność Jana Olbrachta do konfraterni paulinów na Jasnej Górze, do której rodzina Kazimierza Jagiellończyka została przyjęta w $1472 \mathrm{r}^{30}$

Fryderyk Papée podał, że Jan Olbracht nie był nigdy w Częstochowie ${ }^{31}$. Nieznane mu były wzmianki o nieobecności władcy w Krakowie z powodu wyjazdu wraz z królewną Elżbietą do Częstochowy na początku czerwca 1500 r., odnotowane w jednym z zachowanych rejestrów dworzan $^{32}$. Niewątpliwie celem podróży królewskiej była pielgrzymka dziękczynna na Jasną Górę, która wynikała z doświadczeń będących pokłosiem nieudanej wyprawy mołdawskiej w 1497 r., a zwłaszcza choroby mającej wpływ na pogłębienie pobożności Jana Olbrachta w ostatnich latach jego życia ${ }^{33}$. Motywacje religijne leżały także u podstaw podjęcia się przez króla fundacji przepięknie iluminowanych ksiąg liturgicznych, które zostały przekazane do katedry wawelskiej, archikatedry gnieźnieńskiej oraz dla sanktuarium jasnogórskiego ${ }^{34}$.

Źródła dostarczają wielu przykładów mówiących o tym, że na wzór twórców dynastii jagiellońskiej Jan Olbracht podejmował starania o podtrzymanie ukształtowanych przez nich zwyczajów związanych z obchodami świąt kościelnych, przystępowaniem do sakramentów oraz uczestnictwem we mszach świętych. Rejestry wydatków zawierają liczne zapisy odnoszące się do odświętnych i codziennych praktyk religijnych zachowywanych na jego dworze królewskim. Przykładowo w księdze 20 rachunków królewskich odnotowano zakup świec na roraty, które były odprawiane w okresie adwentu w kaplicy monarszej ${ }^{35}$. Na podstawie szczegółowych spisów wydatków z roku koronacji Jana Olbrachta wiadomo, że w Boże Narodzenie władca uczestniczył we mszy o północy oraz w uroczystej sumie sprawowanej w dzień święta ${ }^{36}$. W Wigilię przestrzegał postu i spożywał dania rybne ${ }^{37}$. Podczas świąt Bożego Narodzenia rozdawał zwyczajową kolędę, czyli datki pieniężne dla

\footnotetext{
28 Rk 22, k. 29v. Zob. U. Borkowska, Dynastia Jagiellonów, dz. cyt., s. 450.

29 Zob. U. Borkowska, Dynastia Jagiellonów, dz. cyt., s. 449-451.

30 Taż, Pobożność rodziny, dz. cyt., s. 29; taż, Polskie pielgrzymki Jagiellonów, dz. cyt., s. 195; taż, Dynastia Jagiellonów, dz. cyt., s. 415.

31 F. Papée, dz. cyt., s. 10. Por. Zbiór dokumentów, dz. cyt., s. 268, przyp. 24.

32 Archiwum Główne Akt Dawnych w Warszawie, Archiwum Skarbu Koronnego, Oddział 86, Rachunki z przychodów i wydatków na potrzeby wojska, sygn. 4, k. 54v, 138v. Zob. A. Nalewajek, dz. cyt., s. 77.

33 Po powrocie z wyprawy mołdawskiej w lutym 1498 r. z pielgrzymką dziękczynną na Jasną Górę udał się królewicz Zygmunt. Zob. U. Borkowska, Dynastia Jagiellonów, dz. cyt., s. 416.

34 B. Miodońska, Rex Regnum i Rex Poloniae w dekoracji malarskiej Graduału Jana Olbrachta i Pontyfikału Erazma Ciołka. Z zagadnień ikonografii władzy królewskiej w sztuce polskiej wieku XVI, Kraków 1979, s. 106, 115-116; W. Terlecki, Miniatury Graduału z fundacji króla Jana Olbrachta, Lwów 1939, s. 9; Z. Rozanow, Gnieźnieński Kodeks Jana Olbrachta, „Studia Renesansowe”, 4/1964, s. 425.

35 Rk 20, k. 91v. Zob. U. Borkowska, Dynastia Jagiellonów, dz. cyt., s. 400.

36 Rk 20, k. 14, 18v. W wigilię Bożego Narodzenia czyniono przygotowania do uroczystej liturgii, np. zakupywano świece do ołtarza. Rk 20, k. 17v. Podobny wydatek na świece w związku ze świętami Bożego Narodzenia miał również miejsce w 1494 r., gdy król przebywał w Elblągu. Rk 22, k. 42v.

37 Rk 20, k. 18.
} 
osób przebywających na dworze królewskim i służby ${ }^{38}$. Z zapisów dotyczących obchodów świąt Bożego Narodzenia w roku 1494, które Jan Olbracht spędził w Elblągu, wynika, że na potrzeby związane z odprawianiem nabożeństw oraz datkami na rzecz Kościoła przeznaczono wówczas kwotę 20 florenów ${ }^{39}$.

W okresie Wielkiego Postu król, podobnie, jak jego poprzednicy, przygotowywał się do świąt wielkanocnych poprzez przystąpienie do spowiedzi, a także przyjęcie Komunii św. oraz przez sprawowanie praktyk pokutnych w Wielkim Tygodniu. Zapewne w charakterze spowiednika i kaznodziei na dworze królewskim w latach 1496-1497 pojawiał się Jan z Oświęcimia, zwany Sacranusem ${ }^{40}$. W 1496 r., podczas pobytu króla na sejmie w Piotrkowie, po Wielkanocy otrzymał on za posługę kwotę 14 florenów ${ }^{41}$. W połowie marca następnego roku Jan z Oświęcimia, już z tytułem doktora, przebywał na dworze królewskim w Sandomierzu. Dostał wtedy wynagrodzenie w wysokości 12 florenów ${ }^{42}$. O odbywaniu przez króla Jana Olbrachta spowiedzi w okresie Wielkiego Postu świadczy wzmianka z 1501 r. Informuje ona o przekazaniu z polecenia królewskiego 10 florenów za spowiedź nieznanemu z imienia spowiednikowi. Wydatek ten miał miejsce około niedzieli Laetare ${ }^{43}$. W tym samym terminie do spowiedzi przystępował później król Zygmunt I, którego praktyki religijne są lepiej udokumentowane w dobrze zachowanych rachunkach nadwornych z czasów jego panowania ${ }^{44}$.

Wielki Tydzień był czasem wypełniania przez władcę praktyk pokutnych. Za przykładem swych poprzedników Jan Olbracht odwiedzał pobliskie kościoły i rozdawał jałmużnę dla ubogich ${ }^{45}$. W 1493 r. podczas pobytu w Poznaniu w Wielki Piątek, jak już wcześniej wspomniano, król udał się do sanktuarium Bożego Ciała. Poznańskie szpitale, a także klasztory otrzymały w tych dniach datki dla ubogich. Z wykazów wydatków nadwornych wynika, że w Wielkim Tygodniu na jałmużnę dla szpitali wydano 12 grzywien $^{46}$. Ponadto w Wielki Czwartek rozdzielone zostały dla ubogich dwie kwoty, w wysokości 9 florenów oraz 2 grzywien, które z własnej kiesy założył sekretarz królewski Maciej Drzewicki ${ }^{47}$. Oprócz wsparcia w postaci datków pieniężnych, w ramach jałmużny rozdawano sukno, a przede wszystkim płótno. Wspomniany Maciej Drzewicki w Wielką Sobotę pożyczył władcy blisko 90 florenów. Z pieniędzy tych zapłacono wtedy między innymi 4 floreny i 9 groszy za trzy

\footnotetext{
38 Rk 20, k. 17v, 18, 18v, 19, 142v, 143, 143v; Rk 22, k. 3, 3v, 4.

39 Rk 22, k. 42v.

40 Jan z Oświęcimia (zm. 1527) pełnił funkcję spowiednika na dworze królów Jana Olbrachta, Aleksandra Jagiellończyka i Zygmunta I. Był on również przełożonym kaplicy królewskiej Aleksandra Jagiellończyka. Zob. H. Barycz, Jan z Oświęcimia, w: Polski Stownik Biograficzny, t. 10, Wrocław-Warszawa-Kraków 1962-1964, s. 467-468; U. Borkowska, Królewscy spowiednicy, w: Ludzie. Kościół. Wierzenia. Studia z dziejów kultury i społeczeństwa Europy środkowej (średniowiecze - wczesna epoka nowożytna), Warszawa 2001, s. 189; taż, Dynastia Jagiellonów, dz. cyt., s. 149; J. Skibniewska, Dwór królewski Aleksandra Jagiellończyka w latach 1501-1506, Lublin 2015, s. 313,317 .

$41 \quad$ Rk 22, k. 77.

42 Rk 22, k. 98.

43 Rk 28, k. 18v.

44 Zob. U. Borkowska, Dynastia Jagiellonów, dz. cyt., s. 398.

45 Taż, Królewskie miłosierdzie, dz. cyt., s. 689.

46 Rk 20, k. 42v.

47 Rk 20, k. 46v.
} 
sztuki sukna rozdzielonego dla poznańskich kościołów oraz zakupiono 60 łokci płótna dla ubogich, a także rozdano biednym kwotę w wysokości 3 grzywien ${ }^{48}$.

W następnym roku podczas Wielkiego Tygodnia Jan Olbracht wyruszył z dworem królewskim z Krakowa na wyprawę na zjazd dynastyczny Jagiellonów do Lewoczy. Dlatego zwyczajowa jałmużna wielkopostna dla krakowskich szpitali została rozdana przed Niedzielą Palmową. Rozdzielono wówczas kwotę 10 grzywien $^{49}$. W przeddzień wyjazdu władcy przekazano jałmużnę siostrom z konwentu św. Agnieszki w kwocie 3 florenów. Jeden ze szpitali, zapewne prowadzony przy klasztornym kościele Ducha Świętego, otrzymał 4 floreny, a także rozdano 4 floreny na datki dla ubogich ${ }^{50}$. Na czas Triduum Paschalnego oraz świąt wielkanocnych dwór zatrzymał się w Nowym Sączu ${ }^{51}$. Po przyjeździe do miasta Jan Olbracht zachował wielkopiątkowe praktyki monarsze: przestrzegał postu oraz odwiedzał świątynie i rozdawał jałmużnę. Tego dnia dla tutejszych kościołów przekazał kwotę 7 florenów, a także przeznaczył 2 floreny i 17 groszy na jałmużnę dla szpitali i klasztorów ${ }^{52}$. Władca wydał też na datki dla ubogich dodatkowe 7 florenów $^{53}$.

Na podstawie wykazu wydatków znajdującego się w księdze 28 wiadomo, jak wyglądały praktyki religijne Jana Olbrachta w Wielkim Tygodniu i w Wielkanoc w 1501 r. Król przebywał wówczas w Krakowie i w szczególny sposób zadbał o przekazanie jałmużny dla szpitali i zakonów mendykanckich funkcjonujących w mieście. Na polecenie władcy zostały im przekazane datki w złotych monetach. Szpital Ducha Świętego dostał w Wielką Środę kwotę 6 florenów in auro ${ }^{54}$. Inny szpital, prawdopodobnie prowadzony przez bożogrobców, a także klasztory dominikanów i franciszkanów otrzymały w Wielką Sobotę po 3 floreny jałmużny ${ }^{55}$. W Niedzielę Wielkanocną oraz poniedziałek król uczestniczył w nabożeństwach sprawowanych przy konfesji św. Stanisława w katedrze wawelskiej ${ }^{56}$.

Rachunki nadworne Jana Olbrachta odnotowują również wydatki związane z ceremonialnym udziałem władcy w uroczystościach związanych ze świętem Bożego Ciała. Specjalne wynagrodzenie otrzymywali wówczas trębacze, którzy asystowali monarsze, a także dostojnikom Królestwa uczestniczącym w orszaku podczas procesji Bożego Ciała. Wiadomo, że w 1493 r. Jan Olbracht wziął udział w uroczystościach odbywających się w Poznaniu, zaś w następnym roku był obecny na obchodach święta Bożego Ciała w Krakowie ${ }^{57}$.

Ofertoria składane przez władcę podczas mszy sprawowanych w niedziele oraz w dniach, w których przypadały święta liturgiczne, stanowiły jeden z najczęstszych bieżących wydatków królewskich powtarzających się na kartach podręcznych rachunków podskarbińskich. Zwykle wynosiły one po połowie lub jednym florenie, natomiast podczas najważniejszych

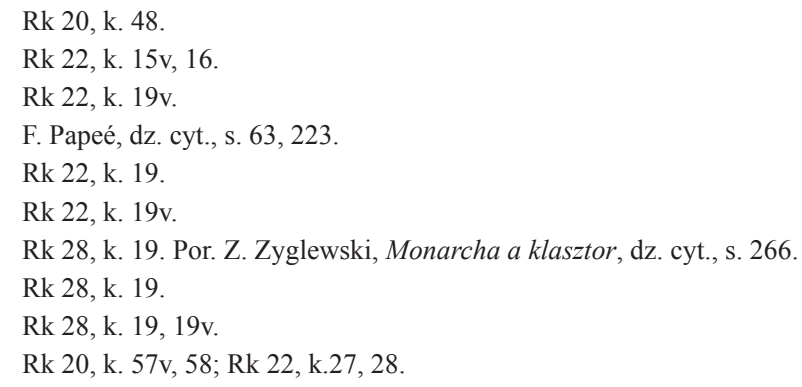


świąt kościelnych monarcha przekazywał na ofiarę od 2 do 4 florenów ${ }^{58}$. Nabożeństwa z udziałem władcy sprawowane były w różnych miejscach znajdujących się na trasach podróży królewskich. Podczas przemierzania ziem podległych Koronie następca Kazimierza Jagiellończyka odwiedził wiele kościołów, katedr i świątyń klasztornych, do których udawał się na msze. Król stał się dobroczyńcą wielu historycznych miejsc kultu religijnego. Wśród nich były między innymi klasztory w Miechowie, Jędrzejowie oraz Chęcinach ${ }^{59}$.

Na podstawie rachunków nadwornych Jana Olbrachta można ustalić częściową listę duchownych związanych z jego kaplicą królewską, której zadaniem było dbanie o praktyki religijne władcy ${ }^{60}$. Początkowo w jej skład wchodziło czterech kapelanów oraz kleryk, zaś w kolejnych latach liczyła ona przeważnie pięciu prezbiterów. Nadworni kapelani Jana Olbrachta w większości pozostają dzisiaj osobami nieznanymi i trudnymi do ustalenia. Funkcję tę pełniło rotacyjnie co najmniej 10 prezbiterów. Jeden z nich, określany jako prepositus prezbiter, najprawdopodobniej był przełożonym kaplicy królewskiej ${ }^{61}$.

Po koronacji Jana Olbrachta na dworze w 1492 r. przebywał nieznany bliżej kapelan Stanisław $^{62}$. W styczniu 1493 r. na liście kapelanów królewskich figurowali prezbiterzy Mikołaj, Stanisław Borzywój i Stanisław Kociołek oraz prepozyt kaplicy nadwornej ${ }^{63}$. Pod koniec 1493 r. w skład kaplicy królewskiej obok prepozyta wchodzili Mikołaj, Stanisław Borzywój oraz dwaj nowi prezbiterzy, Paweł i Wincenty ${ }^{64}$. Funkcję kapelana sprawował wtedy także Stanisław Proszewita, któremu powierzane były misje poza dworem ${ }^{65}$. Podczas wielkiej wyprawy królewskiej na zjazd w Lewoczy wiosną następnego roku capella regia polskiego władcy liczyła sześciu prezbiterów ${ }^{66}$. Po powrocie Jana Olbrachta do Krakowa służbę jako kapelani na dworze pełnili Stanisław, Paweł, Wincenty, Mikołaj oraz nowy kapłan o imieniu Jakub $^{67}$. W skład tej ulegającej rotacjom grupy duchownych pełniących funkcję kapelanów w latach 1493-1494 wchodził ponadto Piotr z Krasnegostawu ${ }^{68}$. Stan zachowania rejestrów rachunkowych nie pozwala poznać kolejnych osób, które należały do kaplicy królewskiej w następnych latach panowania Jana Olbrachta. Ciągłość służby na dworze następnego władcy źródła potwierdzają jedynie w przypadku Stanisława Borzywoja ${ }^{69}$.

\footnotetext{
58 Większe ofiary Jan Olbracht składał na przykład w Dzień Zaduszny. Rk 20, s. 17; Rk 22, k. 69. Zob. U. Borkowska, Królewskie miłosierdzie, dz. cyt., s. 689.

59 Rk 20, k. 29; Rk 22, k. 80v.

60 Zob. U. Borkowska, Capella regia w średniowiecznej Europie (Średniowiecze i wiek XVI), w: Archiwa temporum testes. Źródła historyczne jako podstawa pracy badacza dziejów. Księga pamiatkowa ofiarowana Profesorowi Stanisławowi Olczakowi, red. G. Bujak, T. Nowicki, P. Siwicki, Lublin 2008, s. 48-68; taż, Codzienny i odświętny, dz. cyt., s. 61-85; taż, Dynastia Jagiellonów, dz. cyt., s. 142-152.

$61 \quad$ Rk 20, k. 23v, 66v, 75, 112; Rk 22, 16v, 87.

${ }^{62}$ Rk 20, s. 2, 23, 25.

63 Rk 20, k. 23v, 24, 25.

64 Rk 20, k. 111v, 112.

65 Rk 20, k. 42, 48v. Zapisy w rachunkach z 1494 r. wspominają o obecności na dworze królewskim Jana Olbrachta podczas wyprawy na zjazd do Lewoczy niejakiego Stanisława z Proszowic. Przypuszczalnie był on tożsamy z kapelanem Stanisławem Proszewitą. Rk 22, k. 24v.

${ }^{66}$ Funkcję kapelanów nadwornych nadal pełnili wówczas Stanisław Borzywój, Paweł i Wincenty. W ich gronie pojawił się nieznany bliżej Błażej, a Mikołaja zastąpił Stanisław. Rk 22, k. 16v, 17.

67 Rk 22, k. 34, 34v.

68 Rk 20, k. 86; Rk 22, k. 26v.

69 J. Skibniewska, Dwór królewski, dz. cyt., s. 406.
} 
Posadę kleryka dłuższy czas obejmował niejaki Wojciech Kurnicki ${ }^{70}$. Do jego obowiązków należało między innymi zaopatrzenie kaplicy nadwornej w świece liturgiczne ${ }^{71}$.

Obsadę liturgiczną kaplicy monarszej Jana Olbrachta uzupełniali zawodowi kantorzy, którzy specjalizowali się w wykonywaniu śpiewu liturgicznego ${ }^{72}$. W listopadzie $1495 \mathrm{r}$. na dworze przebywał nieznany kantor nazwany starszym. Był tam również obecny kantor o imieniu Michał ${ }^{73}$. W skład dworu wchodzili chórzyści (cantores), którzy tworzyli chór chłopięcy $^{74}$. Z czasem zatrudniano także organistę ${ }^{75}$. Za panowania Jana Olbrachta na dworze pojawił się Wirowski, będący niezrównanym mistrzem w grze na organach, którego później przyjął do swej kaplicy król Aleksander Jagiellończyk, uważany za wielkiego pasjonata muzycznego ${ }^{76}$.

Następca Kazimierza Jagiellończyka był bliżej związany ze środowiskiem zakonnym dominikanów, którzy pełnili rolę jego spowiedników oraz kaznodziejów ${ }^{77}$. Na podstawie rachunków wiadomo, że przełożony dominikanów krakowskich dostał od króla na sejmie w Piotrkowie w lutym 1493 r. kwotę wynoszącą 15 grzywien $^{78}$. Z kolei w niedzielę 14 lipca 1493 r. w Poznaniu władca przekazał na ręce prowincjała dominikanów kwotę w wysokości 20 grzywien $^{79}$. Podczas pobytu w Lublinie w 1495 r. przebywający na dworze nieznany bliżej kaznodzieja zakonny, zapewne dominikanin, otrzymał 10 florenów $^{80}$.

Z przykładnym wypełnianiem religijnych monarszych praktyk kościelnych przez następcę Kazimierza Jagiellończyka powiązane były zwyczajowe królewskie uczynki miłosierdzia wobec ubogich polegające głównie na udzielaniu jałmużny zakonom mendykanckim, szpitalom oraz biednym. Rachunki nadworne Jana Olbrachta dostarczają bezcennej wiedzy w tym zakresie $^{81}$. Rozdawanie jałmużny królewskiej instytucjom kościelnym wiązało się przede wszystkim z rolą pełnioną przez zakony oraz szpitale w ośrodkach miejskich. Otrzymywały

70 Rk 20, s. 14, 24, k. 25, 28, 112; Rk 22, k. 17, 34v, 56.

71 Rk 22, k. 6v, 21, 22v, 23v, 27, 28, 42v, 57v, 69. Więcej o zadaniach kleryka zob. U. Borkowska, Dynastia Jagiellonów, dz. cyt., s. 144.

72 Rk 20, k. 23; Rk 22, k. 6, 65v, 75, 76.

73 Rk 22, k. 65v, 73.

74 U. Borkowska, Capella regia, dz. cyt., s. 60.

75 Rk 22, k. 39v, 40, 42.

76 Rk 22, k. 85v. Zob. A. Nalewajek, dz. cyt., s. 49; J. Skibniewska, Dwór królewski, dz. cyt., s. 66, 316.

77 U. Borkowska, Królewscy spowiednicy, dz. cyt., s. 188, 189; K. Ożóg, Relacje mendykantów ze środowiskiem dworskim oraz katedralnym na Wawelu do końca XV wieku, w: Mendykanci w średniowiecznym Krakowie, red. K. Ożóg, T. Gałuszka OP, A. Zajchowska, Kraków 2008, s. 24, 26; Z. Zyglewski, Monarcha a klasztor, dz. cyt., s. 257, 261-262.

78 Rk 20, k. 38.

79 Rk 20, k. 67. Chodziło zapewne o Wojciecha z Sieciena, który pełnił funkcję prowincjała w latach 1478-1502. Zob. J. Kłoczowski, Klasztor dominikański w Krakowie w polskiej prowincji dominikańskiej w XIII-XVI stuleciu, w: Cracovia - Polonia - Europa: studia z dziejów średniowiecza ofiarowane Jerzemu Wyrozumskiemu w sześćdziesiata piąta rocznice urodzin i czterdziestolecie pracy naukowej, red. W. Bukowski i in., Kraków 1995, s. 43; K. Kaczmarek, Albert z Siecienia OP (?-1502). Z badań nad elita intelektualna Polskiej Prowincji Dominikanów w XV wieku, w: Scriptura custodes memoriae. Prace historyczne, red. D. Zydorek, Poznań 2001, s. 157. Wojciech z Siecienia uważany jest za jednego ze spowiedników królewskich Jana Olbrachta. Zob. U. Borkowska, Królewscy spowiednicy, dz. cyt., s. 188, 189; Z. Zyglewski, Monarcha a klasztor, dz. cyt., s. 257, 261-262.

$80 \quad$ Rk 22, k. 73.

81 U. Borkowska, Królewskie miłosierdzie, dz. cyt., s. 683, 692; Z. Zyglewski, Rola krakowskich mendykantów, dz. cyt., s. 41-57; tenże, Monarcha a klasztor, dz. cyt., s. 133. 
one datki od władcy z okazji świąt i uroczystości królewskich, a także mniejsze lub większe kwoty przeznaczone na bieżące potrzeby klasztorne.

Głównymi odbiorcami jałmużny królewskiej w Krakowie byli dominikanie z klasztoru Świętej Trójcy ze względu na ich misję duszpasterską sięgającą za pośrednictwem kaznodziejów oraz spowiedników zakonnych dworu monarszego, a także bernardyni, czyli młodsza, obserwancka gałąź braci mniejszych. Obydwa klasztory w ramach udzielania im jałmużny królewskiej były objęte przez Jana Olbrachta opieką materialną ${ }^{82}$. Zapisy w rachunkach informują, że niektóre z kwot przekazywanych przez władcę dominikanom i bernardynom były przeznaczone dla zakonników na zakup ryb ${ }^{83}$. Klasztory otrzymywały również osobne datki na wino mszalne ${ }^{84}$. Tradycyjnie Jan Olbracht udzielał jałmużny również siostrom bernardynkom z konwentu św. Agnieszki, między innymi przekazując datki na wyżywienie ${ }^{85}$.

Jałmużna królewska na rzecz ubogich płynęła do prowadzonych w Krakowie przez zakony przytułków miejskich ${ }^{86}$. Podczas pobytu na zamku wawelskim w 1496 r. Jan Olbracht udzielił wydatnego wsparcia finansowego przyklasztornemu szpitalowi Ducha Świętego. W wigilię święta Zesłania Ducha Świętego przypadającą 21 maja władca podarował szpitalowi 10 florenów ${ }^{87}$. Z wykazów wydatków królewskich z 1496 r. wiadomo, że po święcie Wniebowzięcia 18 sierpnia Jan Olbracht odwiedził klasztor i uczestniczył we mszy w kościele Ducha Świętego, a także przekazał sumę 50 florenów na potrzeby szpitala oraz ofiarował 10 florenów na kościół Świętego Krzyża należący do duchaków ${ }^{88}$.

Następca Kazimierza Jagiellończyka przeznaczał jałmużnę na klasztory mendykanckie i szpitale znajdujące się w innych miastach, w których przebywał w związku z podróżami królewskimi. W czasie dziewięciomiesięcznego pobytu władcy w Poznaniu w 1493 r. zwyczajowa jałmużna trafiała do tutejszych przytułków oraz była przekazywana dla dominikanów, bernardynów oraz karmelitów ${ }^{89}$. Klasztory dominikanów i bernardynów w Poznaniu otrzymały datki królewskie w związku z przyjazdem Jana Olbrachta w lutym 1494 r. ${ }^{90}$

Zwyczaj przekazywania jałmużny dla zakonów mendykanckich i szpitali stanowił stałą praktykę podczas podróży władcy. W rachunkach z 1493 r. odnotowano także informacje o datkach dla klasztorów w Piotrkowie, Kaliszu oraz Kościanie ${ }^{91}$. We fragmentarycznym materiale źródłowym z następnych lat znalazły się zapisy świadczące o dawaniu jałmużny szpitalom i dla zgromadzeń zakonnych w szeregu innych miast goszczących Jana Olbrachta, na przykład w Łęczycy, Radomiu, Toruniu, Lublinie ${ }^{92}$. Podczas swych podróży królewskich

82 Rk 20, s. 11, 20, 21, 22, 24, k. 19, 23, 25v; Rk 22, k. 15v, 16, 16v, 27, 28, 31, 32, 81v, 82, 84. U. Borkowska, Królewskie mitosierdzie, dz. cyt., s. 685.

83 Rk 20, s. 20, k. 19; Rk 22, k. $15 \mathrm{v}$.

${ }_{84}$ Rk 20, s. 24, k. 23; Rk 22, k. 81v, 82. U. Borkowska, Królewskie miłosierdzie, dz. cyt., s. 685.

${ }_{85}$ Rk 22, k. 15v, 27v, 84. O początkach klasztoru zob. szerzej P. Gąsiorowska, Poczatki klasztoru św. Agnieszki (bernardynek) w Krakowie. Rekonesans badawczy, w: Mendykanci w średniowiecznym Krakowie, red. K. Ożóg, T. Gałuszka OP, A. Zajchowska, Kraków 2008, s. 113-130.

86 Rk 20, s. 11, k. 14, 14v, 15v; Rk 22, k. 27, 80v, 85v.

87 Rk 22, k. 80v.

88 Rk 22, k. 85v, 86 .

${ }_{89}$ Rk 20, k. 40v, 42, 45, 49, 49v, 52v, 53, 54, 54v, 55, 57v, 58, 60, 60v, 63, 64v, 65, 67v, 68v, 70, 73, 74, 74v, 77, $78 \mathrm{v}, 79,83 \mathrm{v}, 88,97 \mathrm{v}, 113$.

$90 \quad$ Rk 22, k. 11, 12.

91 Rk 20, k. 30, 30v, 35v, 39v, 98v.

92 Rk 22, k. 10, 11, 12, 19, 22v, 24v, 25, 25v, 35, 38, 41v, 55, 58, 58v, 62v, 73v, 80, 80v; Rk 28, k. 20. 
następca Kazimierza Jagiellończyka znacząco wspierał hojniejszymi datkami rozwój sieci klasztorów bernardyńskich. Tak jak przekazywał dla bernardynów oddzielną jałmużnę w czasie swych pobytów w Krakowie i Poznaniu, tak samo udzielał jej bernardynom w innych miejscach: Kościanie, Łęczycy, Toruniu czy Radomiu ${ }^{93}$. Jedna z większych odnotowanych kwot, wynosząca 12 florenów, przeznaczona została pod koniec 1495 r. dla nowej siedziby bernardynów w Bodzentynie ${ }^{94}$.

Jałmużna dla ubogich była rozdawana również w postaci datków dla recordantes, czyli uczniów odśpiewujących przed królem pieśni i hymny religijne ${ }^{95}$. Pojawiali się oni na dworze królewskim podczas ważniejszych świąt, często także w soboty i niedziele. Jan Olbracht zazwyczaj przekazywał im za występy po kilka groszy, w wyjątkowych sytuacjach nawet po florenie. Recordantes zjawiali się też w różnych miejscach, w których zatrzymywał się władca w czasie podróży królewskich, zwłaszcza podczas ceremonialnych wyjazdów monarszych do miast ${ }^{96}$.

Sfera praktyk religijnych stanowiła nieodłączny element rzeczywistości dworskiej, który został udokumentowany w rejestrach wydatków Jana Olbrachta. We fragmentarycznym materiale źródłowym znalazły się zapisy świadczące o tym, że podtrzymywał on istniejące na dworze królewskim Jagiellonów najważniejsze zwyczaje związane z odświętnym i codziennym ceremoniałem religijnym. Inaczej niż mogłoby się wydawać w świetle obiegowej opinii o tym władcy, pokazują one, że pomimo skłonności do nadużywania uciech życia dworskiego, nie zaniedbywał on ani nie lekceważył regularnego wypełniania spoczywających na nim powinności religijnych oraz systematycznie starał się wydatnie wspierać finansowo instytucje kościelne.

\section{Bibliografia}

\section{Źródła}

Archiwum Główne Akt Dawnych w Warszawie, Archiwum Skarbu Koronnego, Oddział 1, Rachunki Królewskie, sygn. 20, 22, 28; Oddział 86, Rachunki z przychodów i wydatków na potrzeby wojska, sygn. 4; Zbiór dokumentów pergaminowych, sygn. 1886.

Zbiór dokumentów OO. Paulinów w Polsce, t. 2, oprac. J. Zbudniewek, Warszawa 2004.

\section{Opracowania}

Barycz H., Jan z Oświęcimia, w: Polski Słownik Biograficzny, t. 10, Wrocław-Warszawa-Kraków 1962-1964, s. 467-468.

Borkowska U., Dynastia Jagiellonów w Polsce, Warszawa 2011.

Borkowska U., Capella regia w średniowiecznej Europie (Średniowiecze i wiek XVI), w: Archiwa temporum testes. Źródła historyczne jako podstawa pracy badacza dziejów. Ksiega pamiatkowa ofiarowana Profesorowi Stanisławowi Olczakowi, red. G. Bujak, T. Nowicki, P. Siwicki, Lublin 2008, s. 48-68.

\footnotetext{
93 Rk 20, 98v; Rk 22, k. 10, 41v, 55, 58.

94 Rk 22, k. 73v.

95 U. Borkowska, Królewskie miłosierdzie, dz. cyt., s. 685, 686.

96 Zagadnienia te zostały szczegółowo przedstawione przez autorkę w innym miejscu. Zob. A. Nalewajek, dz. cyt., s. $50-51$.
} 
Borkowska U., Codzienny i odświętny ceremoniat religijny na dworze Jagiellonów, w: Theatrum ceremoniale na dworze książat i królów Polski. Materiały z konferencji naukowej zorganizowanej przez Zamek Królewski na Wawelu i Instytut Historii Uniwersytetu Jagiellońskiego $w$ dniach 23-25 marca 1998, red. M. Markiewicz, R. Skowron, Kraków 1999, s. 61-85.

Borkowska U., Jasna Góra w pobożności królów polskich, „Studia Claramontana”, 4/1983, s. 126-145.

Borkowska U., Królewscy spowiednicy, w: Ludzie. Kościół. Wierzenia. Studia z dziejów kultury i społeczeństwa Europy środkowej (średniowiecze-wczesna epoka nowożytna), Warszawa 2001, s. 173-194.

Borkowska U., Królewskie miłosierdzie, w: Kultura średniowieczna i staropolska. Studia ofiarowane Aleksandrowi Gieysztorowi w pięćdziesięciolecie pracy naukowej, red. B. Gawinowa i in., Warszawa 1991, s. 683-694.

Borkowska U., Pietas regia. Formy królewskiej pobożności w późnośredniowiecznej Polsce, w: Król w Polsce XIV i XV wieku, red. A Marzec, M. Wilamowski, Kraków 2006, s. 39-56.

Borkowska U., Pobożność rodziny Kazimierza Jagiellończyka, „Analecta Cracoviensia”, 16/1984, s. 23-41.

Borkowska U., Polskie pielgrzymki Jagiellonów, w: Peregrinationes. Pielgrzymki w kulturze dawnej Europy, red. H. Manikowska, H. Zaremska, Warszawa 1995, s. 185-203.

Borkowska U., Rachunki królewskie jako źródło do poznania praktyk religijnych Jagiellonów, w: Peregrinatio ad veritatem. Studia ofiarowane profesor Aleksandrze Witkowskiej OSU z okazji 40-lecia pracy naukowej, red. U. Borkowska i in., Lublin 2004, s. 47-64.

Dalewski Z., Ceremoniat koronacyjny królów polskich w XV i początkach XVI wieku, „Kwartalnik Historyczny”, 102/1995, z. 3-4, s. 37-60.

Gąsiorowska P., Poczatki klasztoru św. Agnieszki (bernardynek) w Krakowie. Rekonesans badawczy, w: Mendykanci w średniowiecznym Krakowie, red. K. Ożóg, T. Gałuszka OP, A. Zajchowska, Kraków 2008, s. 113-130.

Kaczmarek K., Albert z Siecienia OP (?-1502). Z badań nad elita intelektualna Polskiej Prowincji Dominikanów w XV wieku, w: Scriptura custodes memoriae. Prace historyczne, red. D. Zydorek, Poznań 2001, s. 147-162.

Kłoczowski J., Klasztor dominikański w Krakowie w polskiej prowincji dominikańskiej w XIII-XVI stuleciu, w: Cracovia - Polonia - Europa: studia z dziejów średniowiecza ofiarowane Jerzemu Wyrozumskiemu w sześćdziesiąta piąta rocznicę urodzin i czterdziestolecie pracy naukowej, red. W. Bukowski i in., Kraków 1995, s. 39-46.

Lalik T., O patriotycznym święcie Rozesłania Apostołów w Małopolsce w XV w., „Studia Źródłoznawcze", 26/1981, s. 25-32.

Miodońska B., Rex Regnum i Rex Poloniae w dekoracji malarskiej Graduału Jana Olbrachta i Pontyfikału Erazma Ciołka. Z zagadnień ikonografii władzy królewskiej w sztuce polskiej wieku XVI, Kraków 1979.

Nalewajek A., Na królewskim dworze Jana Olbrachta, „Roczniki Humanistyczne”, 59/2011, z. 2, s. 41-80.

Ożóg K., Relacje mendykantów ze środowiskiem dworskim oraz katedralnym na Wawelu do końca XV wieku, w: Mendykanci w średniowiecznym Krakowie, red. K. Ożóg, T. Gałuszka OP, A. Zajchowska, Kraków 2008, s. 17-39. 
Papée F., Jan Olbracht, Kraków 2006.

Rozanow Z., Gnieźnieński Kodeks Jana Olbrachta, ,Studia Renesansowe”, 4/1964, s. 380-469. Skibniewska J., Dwór królewski Aleksandra Jagiellończyka w latach 1501-1506, Lublin 2015. Starzyński M., Dwa nekrologi Jana Olbrachta (z krakowskiej księgi radzieckiej i Kodeksu Baltazara Behema, „Roczniki Historyczne”, 72/2006, s. 127-136.

Terlecki W., Miniatury Graduału z fundacji króla Jana Olbrachta, Lwów 1939.

Zyglewski Z., Monarcha a klasztor w Polsce późnego średniowiecza, Bydgoszcz 2009.

Zyglewski Z., Rola krakowskich mendykantów w kształtowaniu pobożności Jagiellonów na przełomie XV i XVI wieku, w: Mendykanci w średniowiecznym Krakowie, red. K. Ożóg, T. Gałuszka OP, A. Zajchowska, Kraków 2008, s. 41-57. 